Cahiers $d u$ MONDE RUSSE

\section{Cahiers du monde russe}

Russie - Empire russe - Union soviétique et États indépendants

$56 / 1 \mid 2015$

Fictions d'avenir : sciences et temps des socialismes est-européens

\title{
From experimental psychosis to resolving traumatic pasts
}

Psychedelic Research in Communist Czechoslovakia, 1954-1974

De la psychose expérimentale à la guérison des traumatismes du passé : la recherche psychédélique en Tchécoslovaquie communiste, 1954-1974

\section{Sarah Marks}

\section{(2) OpenEdition}

12 Journals

\section{Electronic version}

URL: http://journals.openedition.org/monderusse/8165

DOI: $10.4000 /$ monderusse.8165

ISSN: $1777-5388$

\section{Publisher}

Éditions de l'EHESS

\section{Printed version}

Date of publication: 1 January 2015

Number of pages: $53-75$

ISBN: 978-2-7132-2475-1

ISSN: $1252-6576$

\section{Electronic reference}

Sarah Marks, «From experimental psychosis to resolving traumatic pasts », Cahiers du monde russe [Online], 56/1 | 2015, Online since 13 July 2019, connection on 09 October 2020. URL : http:// journals.openedition.org/monderusse/8165; DOI : https://doi.org/10.4000/monderusse.8165

This text was automatically generated on 9 October 2020 .

(c) École des hautes études en sciences sociales 


\title{
From experimental psychosis to resolving traumatic pasts
}

\author{
Psychedelic Research in Communist Czechoslovakia, 1954-1974 \\ De la psychose expérimentale à la guérison des traumatismes du passé : la \\ recherche psychédélique en Tchécoslovaquie communiste, 1954-1974
}

Sarah Marks

1 The mid-twentieth century saw an abundance of new theories of human behaviour and mental disorder, many of which were inspired by new developments in broader scientific fields, from cybernetics and genetics, to pharmaceuticals and new technologies of psychological testing ${ }^{1}$. There is a developing historical literature on the development of psychiatry in Western Europe and North America, yet we know little of how these new understandings came to shape psychiatric research in the Communist world. ${ }^{2}$ To date, there has been no substantial historical examination of the work of psychiatrists in Communist Czechoslovakia, despite the country having had a long tradition in research in the field from the inter-war period. ${ }^{3}$ This paper seeks to situate Czechoslovak psychiatric research during the Cold War in a wider international scientific context. I approach these questions drawing on archival material, published research articles and scientific memoirs relating to research groups working on the psychiatric use of psychedelic substances based in Prague across a twenty-year period from 1954 to 1974. Their work sought to investigate the effects of psychedelic substances on the human mind, explore whether the experiences induced by them were comparable with psychosis, and how the effects of these drugs could have psychotherapeutic value in a clinical setting.

2 For the duration of the Communist period, a designated research institute operated at the psychiatric clinic in Prague, and results of studies carried out there, as well as at hospitals across Czechoslovakia, were published in journals such as Czechoslovak Psychiatry (in Czech) or Activitas Nervosa Superior (in English, for distribution abroad), along with a range of monographs distributed by state-run publishing houses. Furthermore, many psychiatrists were able to collaborate and visit researchers abroad, 
both in the west and the USSR. Yet it has been argued that research in the "psy disciplines" was "stifled" in East-Central Europe as a result of Moscow-led dogmatic control. ${ }^{4}$ Such a claim contains the suggestion that researchers in the area lacked academic autonomy, and that science was consequently temporally out of synch with countries where ideological controls were more relaxed: The West, by implication. In this article, I use psychedelic research as a case study to destabilise such historiographical claims, demonstrating that research in psychiatry occurred in a parallel time frame, and with key linkages across East and West during the Cold War. ${ }^{5}$ It is also a case study of a level of permissiveness in the 1960s in Czechoslovakia in a variety of fields of cultural production, of which science was one. As there is a lack of historical writing on international psychiatry more generally in the post-war period, I will embed the psychedelic research project within the context of schizophrenia and psychosis research and the rise of different biological aetiologies of these mental disorders in the 1950s and 60s. In addition, I will explore the profound temporal continuities in practice and knowledge from the inter-war period, with the survival and dominance of psychoanalytic theory in Czechoslovak psychiatry. This came to have a role in shaping LSD psychotherapy practice in Prague through the 1960s until 1974, in spite of explicit state opposition during both the Nazi Protectorate years of the Second World War, and under Stalinism from 1948-1956.

Finally, as time - and the subjective experience thereof - formed a fundamental part of the psychotherapeutic process, I will analyse how the psychiatrists involved in the LSD psychotherapy projects explicitly utilized the psychedelic properties of hallucinogenic drugs to actively manage patients' experiences of their own past within the controlled environment of the clinic and the therapeutic relationship. The potential to use pharmacological and psychological techniques to control and manipulate memories and experiences from the patient's own history for therapeutic purposes fit into a wider progressive project for the improvement of human subjectivity itself. These techniques, according to their advocates, appeared to offer a utopian method for revisiting and ultimately curing historical trauma. ${ }^{6}$ As such, LSD research resonated with broader interests of the socialist regime, particularly in the 1960s, which was concerned both with facilitating future human potential, and with the use of science and technology to further social progress.

\section{Understanding Psychosis}

In 1954, research began on the so-called "experimental psychosis" project, with the participation of a number of researchers across different institutes in Prague, including Jiří Roubíček at the Psychiatric Research Clinic, and Miloš Vojtěchovský at the Research Institute for Human Nutrition. In part, the purpose of these experiments was to record the psychological effects of hallucinogenic drugs ranging from psilocybin, mescaline and adrenochrome, to the newly synthesized lysergic acid (LSD). ${ }^{7}$ During the 1950 s and $60 \mathrm{~s}$ the researchers themselves ingested the various compounds and compared their respective effects ; including their impact on time perception, thought processes, types of optical hallucination, and range of emotional responses experienced. A variety of different tests and questionnaires were used to measure the psychological and physiological effects of the substances, including biochemical measures of metabolism, emotion rating scales and projection tests. ${ }^{8}$ As the effects of some psychotropic drugs - 
and particularly LSD - seemed to mimic psychotic states observed in psychiatric patients with a diagnosis of schizophrenia, the researchers began to formulate trials which compared the effects of autointoxication with clinical psychosis. Similar work was being carried out contemporaneously in the United States, and later Canada and the United Kingdom, but histories of psychedelic research have overlooked the substantial work that occurred on the other side of the Iron Curtain. ${ }^{9}$ With political and social concerns about recreational use of LSD putting an end to such research by the 1960s in the West, the Czechoslovak experiments were the longest running clinical research projects in the field, continuing up until 1974.

5 This research was initiated at a time when understandings of schizophrenia were considered to be in crisis, with few satisfactory theories for the causes of psychotic experiences such as delusions and hallucinations. ${ }^{10}$ Schizophrenia and psychosis featured prominently at the centre of debates in journals internationally, and Czechoslovak researchers were aware of new research perspectives arising from both East and West. With such fundamental psychiatric questions being still open to investigation, a plethora of different approaches to the pathogenic origins of schizophrenia and psychosis began to be explored in the 1950s. Having noticed psychotic symptoms exhibited in patients suffering from infectious neurological diseases such as encephalitis, Soviet researchers became increasingly concerned with potential toxicological and infectious causes of mental illness. ${ }^{11}$ This approach was taken up by Czechoslovak psychiatrists, bolstered by a visit from Russian researcher A.S. Tsistovits in $1957 .{ }^{12}$ There was a particular interest in yeast-induced infections causing psychotic or catatonic symptoms, or the potential use of antibiotics as a treatment modality, sometimes in conjunction with electroshock treatment. ${ }^{13}$ Special consideration was given to the possible relationship between toxoplasmosis infection (a parasitic infection transmitted by cats) and the symptoms of schizophrenia, a theory which originated in Poland in 1953 where patients with a diagnosis of schizophrenia had skin tests for the presence of antibodies indicating the presence of the protozoa Toxoplasma gondii. ${ }^{14} \mathrm{~A}$ similar study was carried out by Czechoslovak researchers in 1957 , and the possibility of a causal link was taken up in other countries of the region. ${ }^{15}$ As historian Richard Noll has argued, suggestions that psychosis could be induced by infection or intoxication had a longer history stretching back to late $19^{\text {th }}$ Century Germany, but this aspect of the history of psychiatry - and indeed its place in current psychiatric theory - is often marginalised. ${ }^{16}$

6 Infection and intoxication were far from the only hypotheses or methodologies under inspection. From 1951, numerous biochemical investigations of patients with mental disorder were carried out by Lubomír Hanzlíček, such as the monitoring of white blood cells as an indicator of the prognosis of mental disorders, or the changes in blood potassium levels as a consequence of insulin shock therapy for psychosis. ${ }^{17}$ In 1962 Hanzlíček, director of the research institute, published a review article in Czechoslovak Psychiatry, which outlined the various biochemical methodologies which were being used to study psychosis abroad. Much of the literature referenced originated from the USA, such as Kelsey's work on nutrition and psychosis, on associations with iodine deficiency and thyroid dysfunction, or Horwitt's studies of liver dysfunction and high protein diets. With such interest in biochemical theories of schizophrenia, the attraction of LSD research is understandable: Czechoslovak researchers were aware of the "serotonin hypothesis" of British psychiatrists Woolley and Shaw, who proposed 
that the hallucinogenic effects of LSD was a result of the antagonism of serotonin (which itself had only been discovered in 1948) in the central nervous system. ${ }^{18}$ The question was therefore raised as to whether this hypothesis be extended to explain the types of hallucinations experienced during schizophrenic psychoses. Recent discoveries in biochemistry, as well as in pharmacology, offered new ways of approaching research into the nature of psychosis and schizophrenia, which could be tested within the laboratory and the clinic. As historian Erika Dyck has described for the North American case, these new methods seemed to offer up not only the promise of finally gaining an understanding of the mysterious aetiology of psychosis, but opened up a new era of modern therapeutic optimism. ${ }^{19}$

\section{Pharmaceuticals, LSD and Psychosis Research}

7 A new generation of psychopharmaceutical drugs, the neuroleptics, had been developed in the early 1950s, and agents of this class including chlorpromazine and reserpine subsequently became available to psychiatric researchers in Eastern Europe for the treatment of psychosis. ${ }^{20}$ At a meeting of the Psychiatric and Neurological Section of the Purkyně Society held in October 1955, Vencovský enthusiastically presented the results of a trial of chlorpromazine held at the psychiatric clinic in Plzeñ. He reported that of 17 patients, only 3 didn't respond "satisfactorily" to the drug (a problem he ascribed to the patients suffering from melancholia), and that the drug had proved effective in patients who had previously not improved after the administration of leucotomy and electroconvulsive therapy. In the published version of the paper, Vencovský and his colleagues concluded that chlorpromazine was the "most excellent" antipsychotic medicine available to psychiatrists. By 1961 a major international conference was organized in Prague on psychopharmacological methods and higher nervous function with attendees from the USA, Canada, United Kingdom, West Germany, and Switzerland in addition to the countries of the Warsaw Pact and various regions of the USSR. ${ }^{21}$ Zdeněk Votava, Czechoslovakia's leading psychopharmacologist and convener of the conference, observed in his concluding address that there was a surprising convergence of thinking across the representatives of different schools of psychopharmacology, "it seems that discrepancies can often be removed and that in fundamental methodological problems a mutual approach of conceptions all over the world is taking place". ${ }^{22}$ Experimentation with LSD in psychiatry must be seen as part of the more general enthusiasm for psychopharmaceutical interventions and the potential for biological and chemical aetiologies and methods of control for mental disorder across Europe and the United States since the 1950s. ${ }^{23}$ As such, the researchers in Prague identified themselves as part of an international scientific community pursuing common questions, and their solidarity with this community outweighed any commitment to local ideological particularisms.

8 A long-standing relationship existed between the Swiss pharmaceutical company Sandoz and the Psychiatric Research Institute in Prague, where the latter had been carrying out clinical trials on a number of psychopharmaceuticals, particularly tranquillizers. ${ }^{24}$ In 1954 Sandoz sent a sample of LSD-25 to the Institute, accompanied by a letter explaining that the drug could induce psychosis-like states, which the manufacturers believed could enhance psychoanalysis and psychotherapy, and enable psychiatrists themselves to experience altered states of mind similar to those of their 
patients..$^{25}$ Shortly afterward, LSD began to be manufactured by the state psychopharmaceutical producer Spofa under the name "Lysergamid" for administration by intramuscular injection. The packaging described the effect of the drug as bringing about

a transitory mental alteration of a psychotic character which may be purposefully utilized therapeutically and diagnostically within a systematic psychotherapy of the certain neuroses and personality disorders, neuroses with expressed anxiety and phobias, obsessive compulsive states, character neuroses, alcohol and drug dependencies, sexual deviations. As an adjuvans [sic] for acceleration and intensification of the therapeutic process. ${ }^{26}$

Production of the drug was highly regulated from the start, prior to international concerns about its use outside medical contexts. A registry of National Centres was held, and these were the only institutions allowed to procure LSD for therapeutic and diagnostic purposes, with prior written permission from the Ministry of Health or the head of the Psychiatric Department. Nurses and therapists administering LSD had to demonstrate expertise in the drug's pharmacodynamics and, in turn, these authorized institutes were obliged to provide regular reports on the "security and health care" of the patients concerned to the Ministry of Health. ${ }^{27}$ While Sandoz discontinued the production of LSD after public concern regarding its effects in the United States, Spofa continued to produce Lysergamid until 1974. Psychiatrist Milan Hausner, who had been actively involved in LSD research until its cessation in 1974, argues that this extended period of research was possible because regulations within Czechoslovakia were strict enough to prevent the drug leaving the clinical setting, so it never became a recreational drug in the way that had happened in North America. ${ }^{28}$

With the experimental psychosis research drawing on similar projects in Canada, the United Kingdom and Switzerland, it is often difficult to see the influence of local political concerns on the content of the research at all. Historian Roger Smith has argued that the psychological disciplines in the region were dominated by Pavlovian ideology, as this was the official doctrine of the Party. ${ }^{29}$ Yet there is no tangible evidence of behaviourist approaches or interpretations within the psychedelic research publications in Czechoslovakia. On the first page of Jiří Roubíček's introduction to his book Experimental Psychosis, Pavlov is indeed the first scientist referenced, but this citation is used to justify experimentation on human subjects as falling within a tradition of psychological testing leading on from Pavlov's laboratory research on dogs. ${ }^{30}$ There is no further discussion of Pavlov or conditioned reflexes in the remainder of the book, and at no stage are these concepts appropriated to explain the phenomena observed. In the introduction, Roubíček argued that animal experiments, despite having provided fruitful data for answering a number of questions about animal behaviour and conditioning, were insufficient for exploring the symptoms experienced by patients suffering from the "endogenous psychoses" : in order for these phenomena to be examined scientifically, healthy human volunteers were required to record their perceptions whilst under the influence of substances which were known to induce hallucinations and other altered conscious states. Pavlov's name was being used here as a means of inscribing the research within an ideologically legitimate experimental tradition of experimentation, but his methods are acknowledged as redundant for the purposes of this specific research. Introductions to research monographs often serve as a political text, particularly in the Communist context, where authors use make references to canonical individuals or concepts in order to frame their research within 
a recognisable worldview that is congruent with the interests of the Party. Historians such as Steven Kotkin have described this phenomena, whereby the official language of the regime came to be used in a variety of everyday texts in the Soviet Union, demonstrating the transformative effect of the regime across different levels of cultural expression..$^{31}$ In the Czechoslovak case, such motifs are included out of political necessity at the beginnings of texts, and in medical literature this was often sufficient to serve as a shield, enabling the actual content of the research to draw on a much broader set of international scientific influences which have little or nothing to do with the regime's official ideology. Such methods of inscription were not only limited to pleasing the regime. Patriotic reference to the national scientific community's historical achievements are also integrated into the text, illustrating the temporal continuities between contemporary experimental work and that of iconic Czech scientists back to the First Republic and the National Renascence. In his introduction to the book, Roubíček made sure to embed the experiments within a long tradition of Czech pharmacological research from before the Second World War, involving auto-experimentation and an interest in the psychological effects of different substances..$^{32}$ In 1924, for example, Otakar Janota published the results of his experiment with ingesting cocaine and morphine together, and recording the results. He reported hallucinations, seeing amusing "lilliputian people," including historical figures..$^{33}$ Later, in 1947 psychiatrist Světozar Nevole experimented with mescaline, concluding that the drug had allowed him to experience four-dimensional space. ${ }^{34} \mathrm{In}$ turn, these authors saw themselves as following a legitimate scientific tradition of auto-experimentation pioneered in the Czech lands by Jan Evagelista Purkyně, the nineteenth century doctor whose name was adopted by the medical society of Czechoslovakia. Similarly, Votava, the key pharmacologist responsible for synthesizing and testing new drugs under the Communist regime self-consciously placed himself within the same tradition. ${ }^{35}$ When new compounds were synthesized by his colleague Miroslav Protiva at the Institute for Pharmacy and Biochemistry, Votava would test them on himself before conducting patient trials. Oldřich Vinař later recalled that, "you sometimes knew there was a new drug around when you saw Votava lying in the corridor." ${ }^{36}$ Vinař also commented that the level of trust and lack of suspicion with regard to exploitation in Czechoslovak society enabled a great deal of leeway for medical experimentation on human subjects, which was further assisted by the Communist regime's lack of bureaucratic intervention in such procedures, and the absence of an ethics committee system. ${ }^{37}$

With experimental trials having been relatively easy to carry out from an institutional perspective, Roubíček and his research group used a variety of tests to compare the responses of intoxicated healthy subjects to those of patients with schizophrenia. Among these were the Rorschach inkblot test, used to determine the subjects unconscious projections. This use of images in exploring the psyche extended to tests that encouraged the subjects to express their experiences artistically using painting, charcoal or ink drawings. Roubíček in particular had a significant interest in the interpretative use of artistic output of patients with mental disorders, having also explored images of aggression produced by patients suffering from epileptic seizures. ${ }^{38}$ Among the healthy volunteers, a number of professional graphic artists were selected, on the expectation that their artistic skills would enable a more accurate depiction of the hallucinatory images they observed. Stanislav Drvota, a psychiatrist at the research clinic later convened a specific research project to explore the potential connection 
between LSD and creativity, employing a number of significant Czech artists, and using some of the result in his book, Personality and Creation (1973), which was concerned with the scientific study of the "self realisation of man as an artist." ${ }_{39}$

In reality, the artists found that the images often shifted at such a rapid rate that it was impossible to track their changing shapes during the course of the experiment. One particular feature, which was recorded by several subjects, was the phenomena of images disintegrating or metamorphosing, often over very short periods of time. Stanislav Grof published a series of sketches in the journal Czechoslovak Psychiatry recording the process of a square clock tower gradually taking on organic curves, with the clock face coming to resemble an owl, and then a cat. ${ }^{40}$ Grof later claimed that his interest in the artistic aspect of the research was what persuaded him to stay in the psychiatric profession. After completing his training, he became disillusioned by the limitations of psychiatric medicine, particularly the psychoanalytic tradition in which he had predominantly been trained, and had begun to organize an alternative career in graphic art. He had gone so far as to arrange an interview with the internationally acclaimed animator Jiř́ Trnka at the Barrandov studios outside Prague when he was given the opportunity to partake in the LSD experiment with Roubíček. ${ }^{41}$

In the Autumn of 1956, just after completing his medical school training, Grof agreed to be a participant in Roubíček's study on the electrical activity of the brain during LSD intoxication..$^{42}$ The experiment involved sitting in a dark room and being exposed to a strobe light, which flashed at different frequencies while the brain's activity was measured by means of electroencephalograph. Grof's brother Paul, also a medical student with an interest in psychiatry, had already been involved in the research and agreed to supervise the session. In the initial part of the session Grof experienced fantastical visual hallucinations and a deep sense of personal psychological insight with such rapidity that he reportedly immediately began to question the validity of his Freudian training up until that point, which suddenly appeared to be limited in its focus on the individual unconscious as developed during childhood. Three hours into the session he was taken into a research cubicle where the research assistant attached the EEG electrodes to his scalp. The stroboscopic light was initiated while he lay down with closed eyes.

I was hit by a vision of light of incredible radiance and supernatural beauty. It made me think of the accounts of mystical experiences I had read about in spiritual literatures, in which the visions of divine light were compared with the incandescence of "millions of suns." It crossed my mind that this was what it must have been like at the epicentre of the atomic explosions in Hiroshima or Nagasaki... I felt that a divine thunderbolt had catapulted my conscious self out of my body. I lost my awareness of the research assistant, the laboratory, the psychiatric clinic, Prague, and then the planet. My consciousness expanded at an inconceivable speed and reached cosmic dimensions. There were no more boundaries or difference between me and the universe. ${ }^{43}$

Electroencephalography, the measure of electrical activity by means of placing multiple electrodes on the scalp, was one of the tests carried out on both sets of subjects in the Experimental Psychosis project, and it was a particular interest of Roubíček's, who had been an early advocate of the use of EEG in medical contexts, publishing in the major British journals Brain and the Journal of Mental Science on the subject in the 1940s..$^{44}$ Czechoslovak researchers were also familiar with work being carried out in EEG technology by cyberneticist Grey Walter in the 1950s and "60s, with Roubíček's close colleague Vladimír Vondráček convening a reading group that 
discussed cybernetic texts, and the prominent neurologist Oldřich Starý visiting Walter at the Burden Neurological Institute in Bristol in December 1959.45 The particular technique used in these experiments was known as "entraining" or "driving" of the brainwaves by exposing the individual to external stimuli at a particular frequency (such as flashing light or rhythmic sounds), so as to "force" the frequency of the brainwaves to correspond with that of the stimulus. ${ }^{46}$ As well as the possibility of measuring external manipulation of brain activity, the EEG had become a popular technology in psychological and psychiatric research because of its perceived ability to produce measurable, objective data on conscious and unconscious states. This not only allowed scientific researchers the opportunity to make observations of mental states beyond the experiential reports of experimental subjects, but also allowed for comparisons of brain activity between different kinds of conscious state, such as dreams and waking psychosis, or sleep and conscious activities. ${ }^{47}$ Its utility in the Prague research project was that it allowed for a direct comparison between the so-called organic psychosis of psychopathology, and the pharmacologically induced states of experimental psychosis. Unlike the findings in most patients suffering from schizophrenia, where the readings were largely normal, LSD had a marked effect on the EEG, causing an increase in the frequency of beta waves as well as alpha waves (by up to $4 \mathrm{c} / \mathrm{s}$ ) and a decline in amplitude. ${ }^{48}$ The hoped for similarities between schizophrenia and experimental psychosis appeared to be weak.

15 Analyses of the graphic images produced by the LSD subjects showed marked differences from what the experimenters characterized as typical artistic features of patients with schizophrenia. The latter presented work with "specific modes of abstraction," which used symbolism that was difficult to understand for other individuals. Organic psychosis was seen to lead patients to focus on very particular parts of a painting, concentrating on detail at the expense of the work as a whole. The LSD subjects tended to record the visual hallucinations they were experiencing, a phenomena that was - according to the researchers - absent in the artwork of schizophrenic subjects. Furthermore, the LSD subjects experienced difficulty in keeping up with the changing imagery they were observing, but their artistic skills remained intact during the course of the experiment. In contrast, the artwork of patients with schizophrenia often displayed deterioration in terms of composition. ${ }^{49}$

Ultimately, the experimental psychosis researchers concluded that there were too many significant differences between experimental psychosis and schizophrenia for the two states to have any functional similarity. The publication and open discussion of such "negative results" - or the refutation of the investigators' original hypothesis - is striking if we compare it with publication trends in biomedical research in the later twentieth century, where publication of negative results became increasingly difficult in peer reviewed journals. ${ }^{50}$ Other contemporaneous researchers cast doubt on the commonality of the experimental psychoses and schizophrenia because the hallucinatory effects of the former did not respond to the recently developed antipsychotic drugs, such as reserpine. Oldřich Vinař in particular, who encouraged the synthesis of reserpine as well as local alternative pharmaceuticals within the same chemical group as the neuroleptic antipsychotics, found that "treating" LSD-induced states with reserpine resulted in bad reactions. As an evangelist for psychopharmaceuticals, who believed a number of his patients with a diagnosis of 
schizophrenia had significantly improved after treatment with antipsychotics, Vinař refused to accept the possibility of "experimental psychosis." 51

The lack of success of the experimental psychosis project at providing definitive evidence on which a biochemical theory of psychosis could be based led some of the researchers to seriously consider non-biological factors. In 1963, drawing on over seventy publications from predominantly American, French and Swiss sources, Stanislav Grof and Zdeněk Dytrych published a comprehensive literature review arguing that Czechoslovak psychiatrists should seriously consider the wealth of international research being carried out on the influence of the family setting on the development of schizophrenia. This article is significant in that it demonstrates the theoretical pluralism of the researchers involved in the experimental psychosis project - the same researchers who made use of biochemical and intoxication methods were also open to psychodynamic and social psychiatric interpretations, above and beyond the possibility of the genetic origins of psychosis in family lines. Outlining theories from Western scholars such as Gregory Bateson, Melanie Klein, Theodore and Ruth Lidz and Stephen Fleck, among many others, the authors charted various concepts of "schizophrenogenic" parents, as well as the possibility of the origin of psychosis being transmitted through interaction with family members already suffering from mental disorders..$^{52}$ This is echoed in their Czech colleague Milan Hausner's work, where he raised the point that "organically oriented psychiatrists" would raise objections to the use of LSD in a psychotherapeutic context, as they would argue that the biochemical and neurological effects of the drug produce an intoxicated and fantastic state, which is extraordinary in terms of mental experience. He countered this proposition, stating that such statements offer no information about the cause or content of the psychopathology experienced under the influence of LSD. Furthermore, he posited that the content of these hallucinations, while they may have been biochemically induced, were fundamentally expressions of individual's experiences and "what the patient has learned at the "school of life":

The mental alterations caused by psychedelics [sic.] are an apparent evidence of fruitlessness of such orthodox and dogmatic conceptions which distinguish between the organic and the functional, between the structural and dynamic and between the physiological and the psychological..$^{53}$

One could easily over-read the influence of socialist concerns in this turn towards theories of social maladaption and inter-personal relationships in the $1960 \mathrm{~s} .{ }^{54}$ Interest in socio-cultural frameworks did come about in a context when other Czechoslovak scientists were calling for a shift away from biological reductionism in understandings of human behaviour and mental illness towards theories that drew on understandings of humans in their social context. Some, such as Oldřich Starý, a Communist Party member who later prominently supported the Prague Spring, were indeed presenting these arguments in terms of Marxist Humanism..$^{55}$ Yet such explicitly political positions were not articulated by any of the psychiatrists involved with LSD research. In large part, their turn away from the biochemical model can be seen as a consequence of the failure of the experimental psychosis project to prove a scientific commonality between psychedelic and psychotic experience. Citing Eugen Bleuler, they admitted the lack of evidence for the so-called "serotonin hypothesis" on which much of their experimental psychosis work had been based, which had posited that hallucinogenic experience was caused by serotonin antagonism of the central nervous system because this was how the effects of LSD were explained. As the study concluded that"true" 
psychosis and the effects of LSD were not comparable, this hypothesis no longer held explanatory weight. Their exploration of new, socially-grounded explanations from the USA was influenced - certainly in Grof's case - by a long-standing interest in psychoanalytic psychiatry. It is remarkable that Grof and Dytrych overtly and unashamedly explain how research on the influence of the family on mental disorder stemmed from the psychoanalytic tradition of Sigmund Freud, via Adolf Meyer in the United States, especially as their article was published a full five years before the relaxation of censorship which came about with

the Prague Spring. ${ }^{56}$ This turn back towards psychoanalysis after the failure of the experimental psychosis project led to new experimentation in the use of LSD as a psychotherapeutic catalyst. In order to understand how such a psychoanalytically orientated project came about in Communist Czechoslovakia, where Freud's work was officially banned, it is necessary to reconstruct the history of psychoanalysis in the region and how it survived into the socialist period.

\section{The Psychoanalytic Tradition in Czechoslovakia}

19 Psychoanalysis was remarkably tenacious in Prague, in spite of its official rejection by the Czechoslovak regime : a key point to note, given the status of psychoanalysis as a hallmark of Communist repression in the historiography. ${ }^{57}$ Prague had itself been an important centre for analysts in the interwar period. Jaroslav Stuchlík, a Czechoslovak psychiatrist, trained in Switzerland during the war, and met Jung at the Burghölzli and later Freud in Vienna. After returning to Prague in 1918, shortly after the new independent state of Czechoslovakia was created, Stuchlík, like many professionally trained Czechs of the younger generation, was posted in Slovakia to help develop infrastructure and facilities there, as it was underdeveloped in comparison to Bohemia and Moravia. As director of the psychiatric hospital in Košice, Stuchlík was able to train a number of his colleagues in psychoanalytic ideas, and exploited the geographical proximity of Slovakia to Budapest in order to invite the famous Hungarian psychoanalyst Sandor Ferenczi to speak at the clinic's seminars on several occasions. ${ }^{58}$ After the Russian Revolution in 1917 Nikolai Ossipov, a prominent Russian psychoanalyst and correspondent of Freud, decided to seek exile in Prague, where he became a lecturer at Charles University and director of the psychiatric out-patients clinic. Shortly after in 1923 he was followed by another Russian psychoanalyst, Bohodar Dosužkov, who emigrated from Baku to train in medicine in Czechoslovakia, and became a key member of the Prague circle. ${ }^{59}$ The height of the Prague Psychoanalytic Circle came in the late 1930s, as Jewish analysts from both Berlin and Vienna sought refuge there : most notably Otto Fenichel, Annie Reich and Henry Lowenfeld. ${ }^{60}$ As a consequence, the 1936 International Psycho-Analytical Congress was held in Czechoslovakia at the spa town of Mariánské Lázně. ${ }^{61}$

Dosužkov himself provided the locus of continuity between the interwar and communist periods, being the only psychoanalyst of the Prague group remaining after the Nazi occupation; the others having perished in the Holocaust or escaped to refuge in the US or Britain. After 1945, Dosužkov resumed his work at the centre of a study group of thirty young psychiatrists interested in psychoanalysis, was appointed a training analyst by Ernest Jones in 1946, and set about establishing an institute and research journal. ${ }^{62}$ The Communist takeover in 1948 and the establishment of a Stalinist 
government in Czechoslovakia led to the abandonment of institutional plans, and many of the psychiatrists who had been involved in the circle gravitated towards more politically acceptable approaches as a means of protecting their careers. ${ }^{63}$

Ironically, Dosužkov himself was well-placed to be protected in the new regime, having been one of the first to translate the works of Pavlov into Czech in the 1930s, and having continued personal correspondence with him after his departure from the USSR. With no political pressure to do so, and even before Czechoslovakia came under Communist control, Dosužkov had enthusiastically promoted Pavlov's work and incorporated conditioned reflex theories into his work - an aspect of his intellectual output which has been ignored by authors who have written about him solely from the perspective of the history of psychoanalysis. Nevertheless, he continued to host an unofficial psychoanalytic group after 1948, albeit with a reduced contingent. At the July 2013 meeting of the International Psychoanalytic Association, held in Prague, his daughter Eugenia Fischer recounted how her father had continued to offer training in psychoanalysis until his death in 1982 , using the family home as a venue. ${ }^{64}$ Ladislav Haas, one of his students, described how recent books and periodicals were sent by mail to the group from Lois Monro, a senior analyst at the British Psychoanalytical Society. Haas, along with Otakar Kučera and Dosužkov himself were made full members of the IPA at the Stockholm Congress in 1963. As well as corresponding with international colleagues, members of the group, although they did not tend to publish on psychoanalytic topics in Czech periodicals, did write in psychoanalytic publications abroad. ${ }^{65}$ In 1971, when Dosužkov was denied the right to travel to Vienna to participate in the IPA's conference, but contact was still maintained, as a group of delegates travelled to Prague to update him. Prague-based psychiatrists in personal contact with members of these networks consequently had a great deal of opportunity to access recent psychoanalytic literature, and this formed the basis for their subsequent LSD psychotherapy research.

\section{The Prague LSD Psychotherapy Projects}

Having received an orthodox training with Bohodar Dosužkov, Stanislav Grof's interpretation of patient responses to LSD hallucinations was informed by his understanding of psychoanalytic practice. He observed that LSD sometimes allowed for "abreaction," meaning that individuals began to recollect past traumas, and sometimes resolve them during the course of their sessions. Grof and Dytrych posited that the drug could be used as a means to accelerate the psychotherapeutic process, as subjects relived experiences from childhood and birth at a rapid rate under the influence of LSD, enabling therapeutic intervention to be achieved within a matter of hours rather than months. ${ }^{66}$

Two research groups were established in the 1960s to explore the uses of LSD in psychotherapy; one under the aegis of Grof and Dytrych at the Prague Psychiatric Research Institute, and another based at the Sadská Clinic just outside Prague run by Milan Hausner and Vladimír Doležal. The Sadská group was particularly international, having co-operated with Hans Leuner in Göttingen from 1963, and having research collaborators on site from Poland and Spain from $1966 .{ }^{67}$ From the outset, the Czech psychoanalyst Kučera was particularly supportive of the use of psychedelics in therapy, as it allowed for what he saw as a more active and intense therapeutic relationship. ${ }^{68}$ 
Grof states that the research was allowed to flourish in part because of the open-mindedness of the director of the Research Institute, Lubomír Hanzlíček, who was able to use his seniority to provide institutional protection for research that was deemed controversial among more conservative psychiatrists of the older generation. ${ }^{69}$

Revisitation of childhood trauma was a common trope in the work of both groups, as was the use of Freudian interpretations of early childhood sexual development and its disruption..$^{70}$ In relation to this, Both Grof and Hausner wrote about the necessity for breaking taboos about physical contact during the sessions. At first for Grof, this ensued out of necessity as patients became very distressed whilst re-living early traumatic experiences. His original approach, inspired by his own orthodox psychoanalytic training with Dosužkov, led him to adopt the "psycholytic" methodology used by British psychiatrist Ronald Sandison, which involved Grof sitting out of the patient's sight with the patient lying on a couch. As Grof became reconciled with the therapeutic value of physical contact he became interested in emerging approaches which, actively made use of touch in psychotherapy. In 1964 he visited London to observe and experience the work of Joyce Martin and Pauline McCririck who had developed "anaclitic" therapy. ${ }^{71}$ McCririck, a London-based psychoanalyst, had been an assistant to American psychiatrist Harold Abramson (who, as was later disclosed, had been involved in research on the military uses of LSD for the CIA). ${ }^{72}$ Drawing from Freud's theory of anaclisis, in which the infant's identification of the love object (usually the mother) was associated with self-preservation, McCririck observed that some patients undergoing LSD psychotherapy appeared to regress into infantile states, requiring affection and comforting. ${ }^{73}$ The therapist consequently stood in for the parental figure. Grof found that in some cases it was simply sufficient to hold the patient's hand, but that some patients required cradling or massage. ${ }^{74}$ One notes that while Hausner and Grof recollect their use of these techniques in their memoir publications many years after the fact, no details of anaclitic therapies are to be found in their published work from the time in Czechoslovakia, which demonstrates the possibilities of a certain liberalism in psychiatric practice which could not be committed to paper in research publications. Grof was aware that although such methods were not uncommon in California and elsewhere in the 1960s, the Czechoslovak psychiatric profession were unlikely to accept it, given that his orthodox psychoanalytic colleagues even advised against shaking hands with patients, lest it inhibited the transference process. ${ }^{75}$

In addition to regression back to childhood, Grof began to observe what he interpreted as patients' recollections of even earlier time periods from their life, including birth and perinatal experience. Drawing on the theories of the Austrian psychoanalyst Otto Rank and his understanding of birth trauma, Grof developed a theory of the mechanism of the psychotherapeutic cure under LSD. He presented this theory at the Psychiatric Research Institute in 1968, asserting that the patient had to re-live the four stages of birth (termed basic perinatal matrices) during the session : intrauterine life, the first stage of delivery, the trauma of the second and more intense stage of delivery, and release into the world. ${ }^{76}$ If the foetus was subjected to threat or trauma in any of these stages, psychological difficulties would present in later life, with particular conditions relating to each stage. In order for the personality to be reconstructed, the trauma had to be resolved by revisiting the birth experience in the therapeutic context. ${ }^{77}$ LSD provided the tool with which these earlier periods in the patient's chronology could be accessed. Grof described the phenomena uncovered during such sessions as 
"Condensed Experience" systems, often abbreviated to "Co-Ex" systems, which he theorised were the patients' constellations of memories and associations of a particular period in their life, combined with a particularly strong emotional charge. The psychedelic properties of the drug appeared to facilitate the reliving and resolution of such "Co-Ex" systems, often through role-playing in which the patient's hallucinations transformed the therapist into the characters who played the most significant role in the traumatic memories. For one of Grof's patients, "Peter", for example, who had been tortured under the Nazi Protectorate regime in Czechoslovakia during the Second World War, the therapist would often transform into a Gestapo officer. ${ }^{78}$ Milan Hausner notes that Grof and his colleague Hanscarl Leuner in Göttingen also described a related "Transphenomenal Dynamic Regulating System" in which, during a

Fragmented, dissociative course of lysergamide intoxication visions representing experience from quite different periods of their life history are marshalling each other... connected to the same emotion. Like in a dream. Most of these entities represent visualized regressive recollections from the patient's life. In the following sessions the working through of these emotionally laden clusters picked them up again and again to the surface till the resolution. ${ }^{79}$

Therapeutic regression sometimes went beyond early experiences, to the "transpersonal" dimension. Two of Grof's research subjects at the Prague clinic appeared to re-live experiences of family members during their sessions. "Nadja," a psychologist aged 50, underwent a hallucination in which she was aged 4 in 1902, dressed in starched clothing and surrounded by family under a staircase, feeling ashamed and unable to live up to the demanding standards of the adults around her. When she later began to describe the memory to her own family, her mother completed the story with the same details that Nadja had recalled, convincing both her and Grof that the experience recollected was actually that of her mother.$^{80}$ In a further session with "Renata," Grof observed that the patient was describing the undergoing an execution at the Battle of the Bilá Hora in 1621. Renata later wrote to Grof once he had emigrated to the USA to inform him that her father had recently been carrying out geneaological research and had discovered that they were descended from a nobleman executed at Bilá Hora, a fact she claimed not to have known at the time ${ }^{81}$ These patient accounts led Grof to explore the work of C.G. Jung regarding the collective unconscious and transpersonal psychology, and such interpretations were echoed in Hausner's work. These references to Jungian and Rankian interpretations were congruent with the work of Ronald Sandison in Britain, whose articles from the Journal of Mental Science are referenced several times in Grof and Dytrych's two-volume project report on "LSD and its use in clinical practice' from $1964 .^{82}$ Also influential was Grof's personal connection with the Transpersonal Psychology movement during the 1960s in California, and his visits to the Esalen Institute in Big Sur. ${ }^{83}$ Although Grof emigrated permanently to the United States in 1967, he maintained contact with colleagues in Czechoslovakia, and his subsequent examination and interpretations of the Prague psychotherapy work appears to have continued to inform the work of his colleagues who were still working on LSD psychotherapy at the Sadská clinic into the 1970s.

Milan Hausner kept a collection of drawings and paintings produced by his patients during his time at Sadská. One such image shows a man reaching down to touch a large stone, around which are also images of dinosaurs. The patient stated, "I am regressing into my childhood, which seems to be a prehistoric age. I am searching, leaving the stones unturned." Hausner described this as having ontogenetic and phylogenetic 
components, indicating that the patient had regressed not only to childhood, but to prehistoric memories of earlier evolutionary states stemming from the collective unconscious. ${ }^{84} \mathrm{~A}$ further example was his colleague, a young psychiatrist named Jakub who "spent five hours of his LSD training in deep phylogenetic and archetypal regression, during which he experienced himself as a primitive reptile standing on four legs - saying nothing, only baring his teeth and trembling". ${ }^{85}$ The concept of the phylogenetic unconscious is normally associated with C.G. Jung, but in Hausner's notes he links it with the work of Konrad Lorenz, the Austrian behavioural scientist, and suggests it operates on an "ethological level" - i.e. that of animal behaviour guided by evolutionary processes ${ }^{86}$ There are numerous patient images in the collection, annotated by Hausner as relating also to the "individual", "perinatal", "cellular", and "collective" unconscious, indicating the different levels of memory or historical periods contained in the human psyche, which he believed could be accessed by use of psychedelic substances. ${ }^{87}$

This research - although obviously unconventional in terms of its theoretical frameworks and conclusions - was by no means the product of peripheral figures: Milan Hausner was manager of a major psychiatric department linked with Charles University Medical School, and president of the Czechoslovak Psychotherapeutic Association. Grof, Roubíček and Vojtěchovský were also significant figures in the psychiatric community, and the projects were given the support of two successive directors of the Psychiatric Research Institute: Vladimír Vondráček and Lubomír Hanzlíček. ${ }^{88}$ Nevertheless, by 1976 the research group at Sadská was closed down as the clinic was merged into another local hospital, and the production of LSD by Spofa had ceased. Milan Hausner later explained this move as the result of both a conservative shift in the psychiatric community, and in the attitude of the regime more specifically during the "Normalization" period after the Soviet invasion of Czechoslovakia in 1969, possibly in light of the anxiety over recreational use of LSD in the United States. It took several years to close the clinic down completely, in part because of the prestige of its director abroad: Hausner had gained esteem as the co-ordinator of the Working Group of Psychotherapists of Socialist Countries, which convened its first meeting at a significant international conference in Oslo in 1973 (an organisation which Hausner privately described as aiming to "co-ordinate psychodynamic activities in Eastern European countries and "export" the unconscious to the USSR"). ${ }^{89}$ Nevertheless, the frequency of inspections and criticisms of LSD therapy increased substantially in the early 1970s, corresponding to a similar turn of events in the USA. ${ }^{90}$

\section{Conclusion}

The Experimental Psychosis and LSD Psychotherapy projects exemplify the limits of narratives which focus upon the isolation and backwardness of scientific research in Czechoslovakia. It is difficult to discern any overt political influence from the Party on the content or methodology of research until the intervention to cease LSD production in 1974. It is also striking that Czechoslovak authors not only extensively cited research from Western Europe and North America, but also frequently published their findings in English in established journals abroad. Research papers were presented at international conferences, and a number of Czechoslovak psychiatrists were also able to travel for study visits, and invite visiting scientists from these destinations to their 
institutes to exchange ideas. Those researchers who could read Russian (who were in the minority), took Soviet research seriously, but Russian-language research had no direct impact on the LSD psychotherapy projects. The Czechoslovak psychedelic research is telling of what Jonathan L. Owen has described as a resilient "independent" culture of non-politically aligned individuals under Communism in Czechoslovakia, particularly in the more liberal years of the $1960 \mathrm{~s} .{ }^{91}$

It is important to acknowledge such cultural products, which did not fall under the binary categories of either overt dissidence and Prague Spring reformists on the one hand, or Party ideologues, calling into question traditional totalitarian narratives. ${ }^{92}$ The absence of Soviet control, and the extent of intellectual and personnel exchange with Western countries, also brings into question the validity of the notion of a coherent Communist "bloc". ${ }^{33}$

While the experimental psychosis and LSD psychotherapy projects were not representative of psychiatric practice across the whole of Czechoslovakia during this period, the longevity of the research programme, its protection by the director of the Psychiatric Research Institute, and the sheer number of psychiatrists, psychologists, nurses - and indeed patients - involved in the projects demonstrates the importance it was accorded by the scientific research community within the medical profession. Furthermore, the degree of collaboration and intellectual exchange across East and West in relation to this research is indicative of the extent to which science originating under Communism was still accorded significant recognition by the international scientific community abroad, subverting Cold War political discourses in the West that characterized civilization behind the Iron Curtain as regressive.

As a number of historians of the Soviet Union have noted, political investment in the improvement of health and scientific progress was a fundamental priority of state socialism. ${ }^{94}$ In Czechoslovakia, a parallel enthusiasm for the primary role of science within the socialist project in the 1960s came to outweigh anxieties about the ideological control over its content, which had been a preoccupation within the Party in the early 1950s. As such, with the need for Czechoslovakia to stay temporally in step with the West in terms of research, international linkages and co-operation were not only tolerated, but actively fostered. Furthermore, if such developments relied on the revival or maintenance of traditions from the pre-1948 period, such borrowings from the past could be overlooked if they allowed for Czechoslovak research to achieve a high level of esteem on an international scale. As such, psychoanalytic concepts and practices could be maintained and built upon, provided their advocates were cautious in the way they were presented in published material.

The psychedelic research projects in Prague, and post-Stalinist socialism more broadly, shared future-orientated discourses of progress, aiming towards the mitigation of suffering and improvement of society and its individuals, through the application of technology and the development of scientific knowledge. What is striking about the LSD psychotherapy research in particular is that this narrative of modernity was not only concerned with future possibilities, but with a great deal of importance being accorded to insight into the past, as a consequence of its psychoanalytic origins. By utilizing pharmaceutical technologies, scientific researchers were not only able to offer a healing process to their patients, but believed they were able to provide them with knowledge, not only of their own personal histories back to the perinatal stage, but also the shared experience of past civilizations and even ancestral species. To those 
involved in the Prague LSD projects, scientific progress, and the relatively liberal conditions for experimentation in the context of socialist Czechoslovakia, appeared to have opened up the possibility for individuals to experience the human past in its entirety, in condensed form, suggesting that scientists had gained a level experimental control over the experience of time itself.

\section{NOTES}

1. The author would like to thank the Arts and Humanities Research Council, and the Institute of Historical Research at the University of London for providing funding which allowed this research to be carried out. I would also like to thank Sonu Shamdasani, Nadgège Ragaru and the peer reviewers for their feedback; and Ross Crockford, Matei Iagher and Jelena Martinovic for helpful discussions on the topic.

2. To date there have been two articles published on the research, based on follow-up studies of participants in the LSD psycho therapy projects. See R.M. Crockford, "LSD in Prague: A Long-Term Follow-Up Study," Multidisciplinary Association for Psychedelic Studies, 17 (2007) : 20-22. Petr Winkler and Ladislav Csémy, "Self Experimentations with Psychedelics Among Mental Health Professionals: LSD in the Former Czechoslovakia," Journal of Psychoactive Drugs, 46 (2014) : 11-19.

3. There has, however, been recent research on medical and scientific fields in the same period. See, for example: Riika Nisonen-Trnka, "Science with a Human Face: The Activity of the Czechoslovak Scientists František Šorm and Otto Wichterle during the Cold War," (PhD Thesis, University of Tampere, Finland, 2012) ; Bradley Matthys Moore, "For the People's Health: Ideology, Medical Authority and Hygienic Science in Communist Czechoslovakia," Social History of Medicine, 27 (2014): 122-43. For comparative perspectives on Soviet psychiatry and psychology, see David Joravsky, Russian Psychology : A Critical History (Oxford, UK : Blackwell, 1989) ; Paul Calloway, Soviet and Western Psychiatry : A Comparative Study (Moor Press, 1992) ; Benjamin Zajicek, "Scientific Psychiatry in Stalin's Soviet Union : the politics of modern medicine and the struggle to define 'Pavlovian' pyschiatry, 1939-1953," (Ph.D. University of Chicago, 2009). For discussions on psychiatry in the region more broadly, see Mat Savelli and Sarah Marks, eds., Psychiatry in Communist Europe (London : Palgrave MacMillan, 2015).

4. Roger Smith, The Fontana History of the Human Sciences (London : Fontana, 1997), p. 189

5. As such, I position this research within a trend in recent historiography of the circulation of knowledge, and particularly science, in the Russian and Soviet sphere of influence. See, for example: Susan Gross Solomon, "Circulation of Knowledge and the Russian Locale," Kritika : Explorations in Russian and Eurasian History, 9 (2008) : 9-26; Mark Walker, ed., Science and Ideology: A Comparative Perspective (London: Routledge, 2003); Yves Cohen "Circulatory Localities : The Example of Stalinism in the 1930s," Kritika : Explorations in Russian and Eurasian History, 11 (2010) : 11-45.

6. Stanislav Grof, Zdeněk Dytrych, LSD a jeho využití v klinické praxi [LSD and its Application in Clinical Practice], (1964). Typescript, Purdue University Special Collections and Archives, Stanislav Grof Papers, MSP1, Box 21, file 2.

7. S. Grof, M. Vojtěchovský, "Experimentální psychóza po použití $200 \mathrm{mg}$ benactyzinu [Experimental Psychosis following the Administration of 200mg of Benactyzine]," Československá 
psychiatrie, 54 (1958): 369-376; H. Bultasová et al., "Psychopatologie a biochemie experimentálních psychoz vyvoláných anticholinergnimi halucinogeny [Psychopathology and Biochemicals of Experimental Psychosis Caused by Anticholinergic Hallucinogens]," Československá psychiatrie, 56 (February 1960) : 14-23 ; S. Grof, M. Vojtěchovský, E. Horacková, "Disorders of associative thinking in various experimental psychoses," Activitas nervosa superior, 3 (May 1961) : 216-217 ; S. Grof et al., "Clinical and Experimental Study of Central Effects of Adrenocrhome," Journal of Neuropsychiatry, 4 (October 1963) : 33-50 ; ibid. ; M. Vojtěchovský, "Psychiatra autoexperiment s halucinogeny [Psychiatric Self-Experimentation with Hallucinogens]," Československá psychiatrie 62, (October 1966) : 303-308.

8. E. Horacková, B. Mosinger, M. Vojtěchovský, "Square test stanovení koncentrace pozornosti v experimentální psychózy indukované diethylamid kyseliny lysergové (LSD-25)] [Square Test for the Evaluation of the Concentration during the Experimental Psychosis Induced by Lysergic Acid Diethylamide (LSD-25)]," Československá psychiatrie 54, (August 1958) : 236-243 ; Bultasová et al., "Psychopatologie a biochemie experimentálních psychoz vyvoláných anticholinergnimi halucinogeny."

9. See Steven J. Novak, "LSD before Leary: Sidney Cohen's Critique of 1950s Psychedelic Drug Research,” Isis, 88 (1997), 87-110 ; Erika Dyck, Psychedelic Psychiatry : LSD from Clinic to Campus (Baltimore: Johns Hopkins University Press, 2010); Matthew Oram, "Efficacy and Enlightenment : LSD Psychotherapy and the Drug Amendments of 1962," Journal of the History of Medicine and Allied Sciences, 69 (2014), 221-250.

10. For more on understandings of schizophrenia, see Sander Gilman, "Constructing Schizophrenia as a Category of Mental Illness" in Edwin R. Wallace, John Gach, eds., History of Psychiatry and Medical Psychology (New York : Springer, 2008), 461-483.

11. A.M. Khaletskii, "Voprosi nekotoriikh infektsionniikh psikhozov v sovremennoi psikhiatricheskoi literature [About Infectious Psychosis in the contemporary psychiatric literature]," Zhurnal nevropatologii i psikhiatrii imeni S.S. Korsakova, 56 (1956) : 395-400 ; T.P. Simson, "Infektsionniie psykhozi [Infectious Psychosis]," Zhurnal nevropatologii i psikhiatrii imeni S.S. Korsakova, 56 (1956) : 389-394.

12. Z. Klimo, O. Andrasinová, I. Major, "Příspěvek k problému toxikologicko infekční psychóz [Contribution to the Study of Toxicological Infectious Psychosis]," Československá psychiatrie, 56 (August 1960): 217-220 ; S.A. Cistovic, "Přednášky o infekčních psychóz našel při návštěvě Československa [Lessons about Infectious Psychosis Attended during the Visit of Czechoslovakia]," Československá psychiatrie, 54, (1958) : 145-148.

13. Klimo, Andrasinová, Major, "Příspěvek k problému toxikologicko infekční psychóz."

14. Z. Koza, "Badania nad toksoplazmoza wsród umyslowo chorych [Research on Toxoplasmosis among Patients with Mental Illness]," Biuletyn Państwowego Instytutu Medycyny Morskiej i Tropikalnej w Gdańsku. Biulleten Gosudarstvennogo Instituta morskoŭ i tropicheskor̆ meditsiny v Gdan'ske, 5 (1953) : 134-137.

15. O. Jirovec et al., "Studien mit dem Toxoplasmintest," Zentralblatt für Bakteriologie, Parasitenkunde, Infektionskrankheiten und Hygiene. 1. Abt. Medizinisch-hygienische Bakteriologie, Virusforschung und Parasitologie. Originale 169, no. 1-2 (July 1957) : 129-159. For details of further studies in the region during this period, as well continued research into the link between toxoplasmosis and schizophrenia up to the $21^{\text {st }}$ century in the United States and the Czech Republic, see E. Fuller Torrey, Robert H. Yolken, "Toxoplasma Gondii and Schizophrenia," Emerging Infectious Diseases 9, 11 (November 2003): 1375-1380; E. Fuller Torrey et al., "Antibodies to Toxoplasma Gondii in Patients With Schizophrenia: A Meta-Analysis," Schizophrenia Bulletin 33, 3 (May 1, 2007) : 729-736.

16. Richard Noll, "Historical Review : Autointoxication and Focal Infection Theories of Dementia Praecox," World Journal of Biological Psychiatry (2004) : 66-72. 
17. L. Hanzlíček, V. Knobloch, "Biochemické vyšetření na inzulinu hypoglykémie; hladina draslíku v krvi po inzulínu šoku [Biochemical Examination of Hypoglycaemia of Insulin ; The Blood Level of Potassium following the Inslulin Shock]," Časopís lékařu cěských 90, 8 (February 23, 1951) : 227-229 ; L. Hanzlíček, "Přímý počet eosinofilů v psychiatrické praxi ; eosinofily jako index v prognóze psychických chorob [Number of Patients with Eosinophilia in Psychiatric Practice ; Eosinophilia as an Index in the Prognostic of Psychological Diseases]", Neurologie a psychiatrie československá 16, 4 (August 1953) : 239-244; L. Hanzlíček, "Humorální koncepce psychických změn; pohledy na biochemii psychóz [Humoral Conception of Psychological Transformations ; Considerations on Biochemistry of Psychosis]," Československá psychiatrie, 53, (1957) : 47-52.

18. D.W. Woolley, E. Shaw "A Biochemical and Pharmacological Suggestion About Certain Mental Disorders," Proceedings of the National Academy of Sciences of the USA, 40 (1954) : 228-231. For more on the history of this hypothesis, see G.K. Aghajanian, G.J. Marek, "Serotonin and Hallucinogens : Review Article," Neurospsychopharmacology, 21, 2S (1999) : 16-23.

19. Erika Dyck, Psychedelic Psychiatry : LSD from Clinic to Campus (Baltimore : Johns Hopkins Press, 2010), p. 7.

20. For more on the history of the neuroleptics, see David Healy, The Creation of Psychopharmacology (Harvard University Press, 2004); for a comparative perspective on the introduction of antipsychotic drugs in East Germany, see Volker Hess, "Psychochemicals crossing the wall. The introduction of psychoactive pharmaceuticals in the German Democratic Republic a perspective from the new historiography of drugs," Medizinhistorisches Journal, 42 (2007) : 61-84.

21. Zdeněk Votava, Oldřich Vinař, Milan Horvath, eds., Psychopharmacological Methods: Proceedings of a Symposium on the Effects of Psychotropic Drugs on Higher Nervous Activity, Held in Prague Form 30 October to 2 November 1961 under the Auspices of the Society for the Study of Higher Nervous Activity, (Prague : State Medical Pub. House, 1963), 9.

22. Symposium on the Effects of Psychotropic Drugs on Higher Nervous Activity, 14.

23. Dyck, Psychedelic Psychiatry : LSD from Clinic to Campus, 8.

24. Stanislav Grof, LSD Psychotherapy: Exploring the Frontiers of the Hidden Mind (Hunter House, Incorporated, 1980), 7.

25. Charles Grob, (1998) "A Conversation with Albert Hofmann," Newsletter of the Multidisciplinary Association for Psychedelic Studies, 8, 3, p. 30-33.

26. Lysergamid-Spofa packaging materials. Reprinted in Milan Hausner, "LSD therapy behind the Iron Curtain, Czechoslovakia 1954-1974," Typescript, Milan Hausner Papers, Purdue University Special Collections and Archives, MSP 76, p. 25.

27. Ibid., 25-26.

28. M. Hausner, LSD : The Highway to Mental Health (Malibu : ASC Books, 2009), 18.

29. Smith, The Fontana History of the Human Sciences, 189.

30. Jiří Roubíček, Experimentální psychosy (Prague : Státní zdravotnické nakladatelství, 1961), 1.

31. Stephen Kotkin, Magnetic Mountain: Stalinism as a Civilization (Berkley: University of California Press, 1997), 198-237.

32. Roubíček, Experimentální psychosy, 2.

33. Otakar Janota, "Hallucinations of Lilliputians during psychosis caused by cocaine combined with morphine," Revue de travaux scientifiques tchécoslovaques. Section deuxième: Mathematiques, physique, chimie, science biologiques, techniques et médicales, Vols. I-III, 1919-1924 (Prague, 1924).

34. Milan Hausner, "Research, Therapy and Misuse of Psychoactive Drugs in Czechoslovakia," in "LSD Therapy Behind the Iron Curtain," 18.

35. Votava, Vinař, Horvath, eds., Psychopharmacological Methods : Proceedings of a Symposium on the Effects of Psychotropic Drugs on Higher Nervous Activity, 7. 
36. "Interview with Oldřich Vinař" in David Healy, The Psychopharmacologists III (London : Arnold, 2000), 62-64.

37. Ibid.

38. J. Roubíček, “Agrese ve výtvarném umění [Agression in Arts]," Československá psychiatrie 62, (1966) : 294-302.

39. Stanislav Drvota, Osobnost a tvorba [Personality and Creation] (Prague : Avicenum, 1973).

40. S. Grof, "A Propos of Optic Disorders in Autoexperiments with Hallucinogens," Československá psychiatrie, 60 (June 1964) : 173-182.

41. S. Grof, "The Great Awakening: Psychology, Philosophy and Sprirituality in LSD Psychotherapy," in Roger N. Walsh and Charles S. Grob, eds, Higher Wisdom (Albany: State University of New York Press, 2005), 121.

42. S. Grof, Realms of the Human Unconscious : Observations from LSD Research (London: Souvenir Press, 1979), xv.

43. S. Grof, When the Impossible Happens: Adventures in Non-Ordinary Realities (ReadHowYouWant.com, 2009), xxxviii-xxxix.

44. J. Roubíček, "Laughter in Epilepsy, with Some General Introductory Notes," The Journal of Mental Science 92, 389 (October 1946) : 734-755 ; J. Roubíček, D. Hill, "Electroencephalography with Pharyngeal Electrodes," Brain : A Journal of Neurology, 71, 1 (March 1948) : 77-87.

45. "Itinerary : Study Visit to British Universities, Czechoslovak University Group, $13^{\text {th }}$ November - $3^{\text {rd }}$ December 1959," Typescript, Oldřich Starý Papers, Archives of the Academy of Sciences of the Czech Republic, Karton 7.

46. Grof, When the Impossible Happens, xxxvi .

47. Kenton Kroker, The Sleep of Others and the Transformations of Sleep Research (University of Toronto Press, 2007), 263.

48. J. Roubíček, "Podobnosti a rozdílnosti schizofrenii a experimentální psychos [Similarities and Differences between Schizophrenia and Experimental Psychosis]," Československá psychiatrie, 54 (1958): 115.

49. Roubíček, "Podobnosti a rozdílnosti schizofrenii a experimentální psychos." For images produced by the experimental subjects, see the appendix of Roubíček Experimentální psychosy.

50. The latter is often used as an example of the negative effect of private commercial interests in the funding of scientific research. While it was the case that Sandoz provided the drug for testing, the researchers themselves were funded by the Czechoslovak Ministry of Health and there was a lack of interference in the publication of research results from either organisation. This case study consequently sheds an interesting light on questions of scientific freedom in research and publication in the Communist context. For a discussion of publication bias from a Science Studies perspective, see Sheldon Krimsky, "Do Financial Conflicts of Interest Bias Research? An Inquiry into the 'Funding Effect' Hypothesis," Science, Technology, \& Human Values 38, 4 (July 1, 2013) : 566-587. For recent debates from within biomedical research on publication bias and negative results, see D.G. Altman, J.M. Bland, "Absence of Evidence Is Not Evidence of Absence," BMJ : British Medical Journal 311, 7003 (August 19, 1995) : 485 ; Christian Pfeffer, Bjorn R. Olsen, "Editorial: Journal of Negative Results in Biomedicine," Journal of Negative Results in Biomedicine 1 (November 12, 2002) : 2 ; Kerry Dwan et al., "Systematic Review of the Empirical Evidence of Study Publication Bias and Outcome Reporting Bias," PLoS ONE 3, 8 (August 28, 2008).

51. "Interview with Oldřich Vinař" in Healy, The Psychopharmacologists III, 64.

52. For a historical discussion of the genesis and fate of the Lidz hypothesis see Anne Harrington, “The Fall of the Schizophrenogenic Mother,"The Lancet, 379, 9823 (2012) : 1292-1293.

53. Milan Hausner, V. Doležal "The Experience of Psychedelics in Outpatient Psychotherapy," Medical Information Service, Spofa-Chemapol, 3, (1966): 79-83. Purdue University Special Collections and Archives, MSP 76, p. 45 
54. S. Grof, Z. Dytrych, “K otazce vlivu rodinného prostředí na vznik a vyvoj schizofrenie [Contribution to the Study of Influence of Family on the Birth and the Development of Schizophrenia]," Československá psychiatrie 59 (1963) : 340-354 ; E. Wolf et al., "On the Method of Evaluating Social Maladaption. Mutual Social Perception Inventory," Československá psychiatrie 60 (1964) : 34-36 ; L. Kubicka et al., "Studie mezilidských vztahů ve skupině hospitalizovaných neurotických pacientů. I. Propojení mezi státem potíží pacienta a jeho interpersonální situaci [Study of Interpersonal Relations within the Group of Neurotic Hospital Patients. I. Relations between the Level of Patient's Difficulties and his Interpersonal Situation]," Československá psychiatrie 61, (1965) : 303-313.

55. Oldřich Starý, "Manifest humanismu [Manifesto of Humanism]," Československá neurologie, 25, (1962) : 77-79.

56. Grof, Dytrych, "K otázce vlivu rodinného prostředí na vznik a vývoj schizofrenie," 340-354.

57. Martin A. Miller, Freud and the Bolsheviks : Psychoanalysis in Imperial Russia and the Soviet Union (New Haven : Yale University Press, 1998). Alexander Etkind, Eros of the Impossible : The History of Psychoanalysis in Russia (Boulder : Westview Press, 1997).

58. Eugenia Fischer, “Czechoslovakia” in Peter Kutter, ed., Psychoanalysis International, vol. 1 : A Guide to Psychoanalysis Throughout the World (London : Routledge, 2013), 36.

59. André Haynal, Psychoanalysis and the Sciences : Epistemology - History (Berkeley : University of California Press, 1993), 176.

60. Russell Jacoby, The Repression of Psychoanalysis : Otto Fenichel and the Freudians (Chicago : University of Chicago Press, 1986), 8.

61. "Papers given at the $14^{\text {th }}$ International Psycho-analytical Congress, Marienbad, 1936," Wellcome Collection Archives and Manuscripts, PP/SHF/F/2/51.

62. Ladislav Haas, "Letter to the Editor," International Review of Psycho-Analysis, 10 (1983) : 237. 63. For further detail on psychoanalysis under Communism, see Michael Šebek, "Psychoanalysis in Czechoslovakia," Psychoanalytic review, 80 (1993) : 433-439 ; J. Kocourek, "Psychoanalýza v Poválečném Československu [Psychoanalysis in Post-War Czechoslovakia]," Psychoanalýza v Čechách, (1997) : 23-30.

64. Susanne Kitlitschko, "The Prague Psychoanalytic Study Group 1933-1938 : Frances Deri, Annie Reich, Theodor Dosužkov, and Heinrich Löwenfeld, and Their Contributions to Psychoanalysis," The International Journal of Psychoanalysis, 94 (2013) : 1196-1198.

65. Ibid.

66. Grof, Dytrych, LSD a jeho vyuzití v klinické praxi. Část 2, 107.

67. Hausner, "LSD therapy behind the Iron Curtain, Czechoslovakia 1954-1974," 18.

68. Ibid., 19.

69. Grof, Realms of the Human Unconscious, xv.

70. See, for example, the case of "Renata" in Grof, Realms of the Human Unconscious, 83-88; or the case of "Paul" in Hausner LSD : The Highway to Mental Health, 171-173.

71. S. Grof, LSD Psychotherapy: Exploring the Frontiers of the Hidden Mind (Hunter House, Incorporated, 1980), 122.

72. Joint hearing before the Select Committee on Intelligence and the Subcommittee on Health Resources, United States Senate. Ninety-Fifth Congress, First Session (Washington: US Government Printing Office, August 3, 1977).

73. Harold Alexander Abramson, The Use of LSD in Psychotherapy and Alcoholism (Bobbs-Merrill, 1967), 223 ; Sigmund Freud On Narcissism (Standard Edition, XIV,1914), 87-90.

74. Grof, LSD Psychotherapy, 122.

75. Grof, LSD Psychotherapy.

76. Hausner, "LSD therapy behind the Iron Curtain, Czechoslovakia 1954-1974," 18.

77. Later sumarised in English in Grof, Realms of the Human Unconscious, 102-103.

78. S. Grof, LSD : Doorway to the Numinous (Bear \& Co, 2009), 82. 
79. Hausner, "LSD therapy behind the Iron Curtain, Czechoslovakia 1954-1974," 33.

80. Ibid., 164.

81. Ibid., 165-167.

82. Grof, Dytrych, LSD a jeho využití v klinické praxi. Část 1, Přehled literatury, 207.

83. S. Grof, "A Brief History of Transpersonal Psychology" (c. 2005) [ http:// www.stanislavgrof.com/pdf/A_Brief_History_of_Transpersonal_Psychology-Grof.pdf accessed 26/5/14] ; S. Grof, “Account of a dream at Esalen Institute, c. 1963-1967," Manuscript, Stanislav Grof Papers, Purdue University Special Collections and Archives, MSP 1, Box 1, Folder 1.

84. Hausner, "LSD therapy behind the Iron Curtain, Czechoslovakia 1954-1974," appendix.

85. Hausner, LSD : The Highway to Mental Health, 170.

86. Ibid., 66.

87. Ibid., appendix.

88. The former also having been the editor of the main State-published psychiatric journal, Československá psychiatrie.

89. Hausner, "LSD therapy behind the Iron Curtain, Czechoslovakia 1954-1974," 106; T.E. Mogstad, F. Magnussen, eds., What Is Psychotherapy? (Karger, 1975).

90. Hausner, LSD : The Highway to Mental Health, 256. Grof moved to the US in 1967 following a series of study trips to the Esalen Institute in the 1960s, and found that almost immediately after his relocation LSD research was halted as a consequence of legal prohibition after a number of high profile media cases of the abuse of psychedelic drugs. Grof consequently went on to develop holotropic breathwork techniques to mimic the psychological experiences and subsequent psychotherapeutic possibilities that LSD had allowed during his earlier research. See Grof, The Realms of the Human Unconscious.

91. Jonathan L. Owen, Avant-Garde To New Wave: Czechoslovak Cinema, Surrealism and the Sixties (Berghahn Books, 2013), 41.

92. Ibid.

93. For recent historiographical discussion on this question, see Justine Faure, Sandrine Kott, Le bloc de l'Est en question, Vingtième Siècle, 109 (2011). For more on cultural exchange between East and West see Simo Mikkonen, "Beyond the Superpower Conflict: Introduction to VJHS Special Issue on Cultural Exchanges During the Cold War," Valahian Journal of Historical Studies, 10 (2013).

94. Zajicek, "Scientific Psychiatry in Stalin's Soviet Union : the politics of modern medicine and the struggle to define 'Pavlovian' pyschiatry, 1939-1953."

\section{ABSTRACTS}

Drawing on research papers, archives and scientific memoirs, this paper reconstructs the psychedelic research projects developed in Prague between 1954 and1974, situating psychiatric research in Communist Czechoslovakia within the transnational context of Cold War science. It traces attempts to induce experimental psychosis as a means of exploring the aetiology of schizophrenia; as well as the resilience of psychoanalytic theory and practice in Czechoslovakia, illustrated by approaches to psychotherapy using LSD as an accelerant. Time - and the subjective experience thereof - formed a fundamental part of the psychotherapeutic process, and the researchers explicitly utilized hallucinogenic drugs to actively manage patients' memories of 
their own past within the controlled environment of the clinic and the therapeutic relationship. The use of pharmacological and psychological techniques to control experiences from the patient's history for therapeutic purposes fitted into a wider progressive project for the improvement of human subjectivity itself: they appeared to offer a utopian method for revisiting and ultimately curing trauma. Ultimately, psychedelic research resonated with broader interests of socialist modernity, which was concerned with facilitating future human potential, and the use of science and technology to further social progress.

Fondé sur des archives, des mémoires scientifiques et de la littérature secondaire, cet article reconstitue les projets de recherche psychédélique développés à Prague entre 1954 et 1974, tout en situant la recherche psychiatrique en Tchécoslovaquie communiste dans le contexte transnational des sciences pendant la guerre froide. Plus précisément, l'article retrace l'histoire des expériences ayant visé à provoquer, à titre expérimental, une psychose en vue d'affiner l'étiologie de la schizophrénie. Il souligne également la résilience, au-delà des changements de régime, de la théorie et de la pratique psychanalytiques tchécoslovaques, une résilience dont atteste l'utilisation thérapeutique du LSD en tant qu'accélérateur. Le temps (et son expérience subjective) était alors envisagé comme une composante fondamentale du processus psychothérapeutique ; les chercheurs, dans l'environnement contrôlé de la relation clinique et thérapeutique, recoururent ouvertement aux drogues hallucinogènes afin d'agir sur les souvenirs des patients. L'utilisation de techniques pharmacologiques et psychologiques pour contrôler les expériences vécues à des fins thérapeutiques s'inscrivait dans un programme plus vaste d'amélioration de la subjectivité humaine elle-même. Ces techniques semblaient en effet offrir une méthode utopique pour revisiter le traumatisme et, in fine, le guérir. En dernier ressort, la recherche psychédélique entrait en écho avec les visées plus larges de la modernité socialiste dont le propos était de faciliter le développement du potentiel humain et de placer la science et la technologie au service du progrès social.

\section{AUTHOR}

\section{SARAH MARKS}

University of Cambridge, UK, svm31@cam.ac.uk 